\title{
Comparison of the Performance of Grafted and Ungrafted Coffee Trees ${ }^{1}$
}

\author{
T. Singh Dhalival, A. Morales Muñoz, J. \\ Jordán Molero, and P. Meléndez González ${ }^{2}$
}

\section{INTRODUCTION}

Coffee production is an important agricultrual industry in the CentralWestern Mountainous Region of Puerto Rico. Most of the coffee produced in this Region comes from Puerto Rican, Bourbon, and Columnaris varieties of Coffea arabica L. The other varieties and species of Coffea are planted on only a very small scale.

Because coffee is a tree crop, development of its commercially desirable and true-breeding varieties through hybridization, followed by inbreeding and selection, takes a long time, and is generally quite expensive. Therefore, vegetative propagation of commercially desirable coffee hybrids can save considerable time and expense $(3,5) \cdot{ }^{3}$ Coffee selections and varieties which are susceptible to soil-borne diseases and insects, and possess weak root systems, can be better utilized for commerical production by grafting them on resistant or tolerant rootstocks, possessing well-developed root systems. Old and inferior coffee trees can be inproved by topworking them with scions from high-yielding and also otherwise superior coffee selections and varieties.

In 1954 the Agricultural Experiment Station of the University of Puerto Rico, Río Piedras, P.R., started a project on vegetative propagation of coffee. The research work carried on under this project concerning the development of techniques for multiplication of coffee plants by stem-cuttings and grafting, and topworking of old coffee trees, was published previously $(4,6)$. Detailed study of the comparative performance of grafted and ungrafted coffee trees in field trials, is briefly presented in this paper.

${ }^{1}$ This is the final technical report of the Federal-Grant Research Project Hatch 24, Vegetative Propagation of Coffee, carried on under the Leadership of the senior author.

2 Plant Breeder, Research Assistant, Research Assistant, and Assistant Phytopathologist, respectively, Agricultural Experiment Station, Mayagüez Campus, University of Puerto Rico, Río Piedras, P.R. The authors are very grateful to A. Cruz Miret and A. Torres Sepúlveda of this Station for cooperation to the research work.

${ }^{3}$ Italic numbers in parentheses refer to Literature Cited p. 303. 


\section{EXPERIMENTAL PROCEDURES}

The following three field trials were established for detailed study of the comparative performance of grafted and ungrafted coffee trees:

\section{FIELD TRIAL 25}

Trial 25 was located at Castañer, P.R., at an elevation of about 2,000 feet above sea level. The soil type was Alonso clay. It was moderately steep with eastern exposure.

The coffee trees were planted in September 1959. The planting distance was $8 \times 8$ feet. Eight types of coffee trees were included: Puerto Rican and Bourbon trees ungrafted and the same grafted on Columnaris, Excelsa (C. excelsa Chev.) and Robusta (C. canephora Pierre) rootstocks. A balanced incomplete-block design with two treatments (plant types) per block and four blocks per replication was used. The total number of replications was seven. The number of plants of each treatment within a block was six.

There was about 50-percent natural shade in the field. Cultural practices commonly recommended for commercial coffee production were carried on (8).

The coffee plants available for planting in this field trial were of variable height. During 1962 they were severely attacked by hormiguilla, Myrmelachista ramulorum Wheeler. In spite of using methods commonly recommended for control of this insect, a large number of coffee trees died and many severely defoliated. Therefore, from this field trial data only as regards to rootstock and scion incompatibility and quality of coffee produced are presented.

\section{FIELD TRIAL 27}

Trial 27 was located at Castañer, P.R., at an elevation of about 2,000 feet above sea level. The soil type was Alonso clay. It was moderately steep with eastern and northeastern exposures.

The coffee trees were planted in December 1959. The planting distance was $8 \times 8$ feet. Four types of coffee trees were included: Bourbon trees ungrafted, and those grafted on Columnaris, Excelsa, and Robusta rootstocks. A balanced incomplete-block design with two treatments (plant types) per block and two blocks per replication was used. The total number replications was 12 . The number of plants of each treatment within a block was six.

There was 10- to 20-percent natural shade in the field. The cultural practices as commonly recommended for commercial coffee production were carried on (8).

The coffee plants available for planting in this field trial were fairly uni- 
form as to their height. From them data on rootstock and scion incompatibility, effect of root rot disease, growth characters of coffee trees, coffee yield, and bean characters are presented.

\section{FIELD TRIAL L-5}

Field trial L-5 was located at the Agricultural Experiment Substation, Adjuntas, P.R. at an elevation of about 1,900 feet above sea level. The soil type was Alonso clay. It was moderately steep with eastern exposure.

The coffee trees were planted in May 1963. The planting distance was $6 \times 6$ feet. Twelve types of coffee trees were included: Puerto Rican and Bourbon trees ungrafted and those grafted on Columnaris, Excelsa, Robusta, Stenophylla (C. stenophylla G. Don) and Murta (C. arabica L.). All the 375 plants available were planted at random.

There was about 50-percent natural shade in the field. The cultural practices as commonly recommended for commercial coffee production were carried on (8).

Data on rootstock and scion incompatibility are presented, from this field trial but no other data could be collected from it.

\section{COLLECTION OF DATA FROM THE FIELD TRIALS}

The grafted coffee trees were observed for symptoms of rootstock and scion incompatibility. The trees apparently dead from the root rot disease were noted. The upright growing stems or shoots thicker than 1 inch, and arising within 60 inches from the ground level were counted. The girth of the main stem was measured at ground level. Height of the trees was measured vertically from ground level to the apical bud, without straightening the bent trees.

From field trials 25 and 27 ripe coffee cherries were harvested as in commercial coffee plantings. During the fourth crop from each plant type a random sample of 101 to 140 pounds of ripe cherries was depulped and demucilaged. The beans were thoroughly dried in the sun before removing the parchment. The moisture contents of the clean beans were determined with an accurate moisture-meter. Then, for each plant type, the weight of ripe cherries required to produce a pound of clean beans with 12-percent moisture content was determined.

The clean coffee beans were graded for size by passing them through three types of sieves as used commercially $(1,2)$. The descriptions and uses of these sieves are briefly as following:

Sieve No. 15

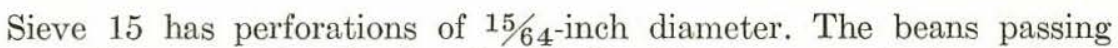
through it are considered to be of small size. The beans retained over it are of medium size and are considered to be good commercial-grade coffee. 
Sieve No. 17

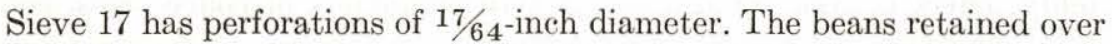
it are of large size. They are considered to be top export-grade coffee.

Sieve No. 18

Sieve 18 has perforations of $18 / 64$-inch diameter. The beans retained over it are exceptionally large. They are also considered to be top export-grade coffee.

\section{EXAMINATION OF RANDOM SAMPLES}

Small random samples of clean coffee beans from each plant type were studied visually to determine the number of beans per liter and the proportions of giant beans, peaberry beans, flat beans, and triangular beans.

Samples each of 100 randomly selected clean beans from each plant type were used to determine their weight, volume of water displaced by them, and their specific gravity.

\section{RESULTS AND DISCUSSION}

STUDIES ON ROOTSTOCK AND SCION INCOMPATIBILITY

Grafted coffee trees with scions from Puerto Rican and Bourbon coffees and rootstocks from Columnaris, Excelsa, Robusta, Stenophylla, and Murta coffees, were studied as to the occurrence of incompatibility.

Abnormal swelling at the graft union and condition of scion, such as weak growth, yellow leaves, defoliation, dying back of branches, and complete drying up, were observed to be the symptoms of rootstock and scion incompatibility. However, it was also noted that when the grafted coffee trees had produced several crops, distinct swelling at the graft union was the most reliable symptom indicating this condition.

Very high percentages of the grafted coffee trees with Stenophylla and Robusta rootstocks and Puerto Rican and Bourbon scions showed symtoms of incompatibility. Hence these rootstocks were considered to be unsuited to these scion varieties.

Murta, Columnaris, and Excelsa rootstocks seemed to be highly compatible with Puerto Rican and Bourbon scions (tables 1 and 2).

\section{EFFECT OF ROOT ROT DISEASE ON GRAFTED AND UNGRAFTED COFFEE TREES}

The ungrafted Bourbon trees suffered from root rot disease relatively more than those grafted on Columnaris, Excelsa, and Robusta rootstocks (table 3).

Root rot caused by the fungus Fusarium oxysporum f. coffeae (F. bulbigé- 
TABLE 1.-The rootstock and scion incompatibility of grafted coffee tress growing in field trials 25 and 27 at Castañer, P.R. ${ }^{1}$

\begin{tabular}{c|l|c|c}
\hline Rootstock & \multicolumn{1}{|c|}{ Scion } & Grafted coffee trees & $\begin{array}{c}\text { Proportion showing the } \\
\text { incompatibility }\end{array}$ \\
\cline { 2 - 3 } & & Number & Percent \\
Columnaris & Puerto Rican & 42 & 0 \\
Do. & Bourbon & 114 & 0 \\
Excelsa & Puerto Rican & 42 & 7.14 \\
Do. & Bourbon & 114 & 5.26 \\
Robusta & Puerto Rican & 42 & 50.00 \\
Do. & Bourbon & 114 & 28.95 \\
\hline
\end{tabular}

1 The data were collected in May 1965.

${ }^{2}$ Distinct swelling at the graft union was the only symptom of incompatibility considered.

TABLE 2.-The rootstock and scion incompatibility of grafted coffee trees growing in field trial L-5 at the Agricultural Experiment Substation, Adjuntas, P.R. ${ }^{1}$

\begin{tabular}{c|l|c|c}
\hline Rootstock & \multicolumn{1}{|c|}{ Scion } & Grafted coffee trees & $\begin{array}{c}\text { Proportion showing the } \\
\text { incompatibility }\end{array}$ \\
Columnaris & Puerto Rican & Number & Percent \\
Do. & Bourbon & 19 & 5.26 \\
Excelsa & Puerto Rican & 26 & 3.85 \\
Do. & Bourbon & 28 & 0 \\
Robusta & Puerto Rican & 89 & 2.25 \\
Do. & Bourbon & 57 & 13.25 \\
Stenophylla & Puerto Rican & 13 & 29.82 \\
Do. & Bourbon & 2 & 61.54 \\
Murta & Puerto Rican & 8 & 50.00 \\
Do. & Bourbon & 13 & 0 \\
\hline
\end{tabular}

1 The data were collected in April 1965.

${ }^{2}$ All the symptoms of incompatibility mentioned in the text were considered.

TABLE 3.-The effect of the root rot disease on grafted and ungrafted coffee trees growing in field trial 27 at Castañer, P.R. ${ }^{1}$

\begin{tabular}{l|c|c|c|c}
\hline \multicolumn{1}{c|}{ Rootstock } & Scion & Trees & Trees dead & Proportion dead \\
Columnaris & Bourbon & 72 & Number & Percent \\
Excelsa & Do. & 72 & 18 & 25.00 \\
Robusta & Do. & 72 & 23 & 31.94 \\
Ungrafted & Do. & 72 & 20 & 27.78 \\
& & & 40.28 \\
\hline
\end{tabular}

${ }^{1}$ The data were collected in May 1965. 
num var. coffeae (Alvárez G. (Wellm)) is the most harmful disease of coffee in Puerto Rico. Every year numerous trees of commercially grown coffees die of it. Use of tolerant or resistant rootstocks is an important method for reducing losses from this disease ( $(7)$.

\section{GROWTH CHARACTERS OF GRAFTED AND \\ UNGRAFTED COFFEE TREES}

The grafted and ungrafted coffee trees did not differ much as to number of stems or shoots, girth of the main stem, and the height of the tree (table $4)$.

These results indicate that Puerto Rican and Bourbon trees ungrafted, and those grafted on Columnaris, Excelsa, and Robusta rootstocks, require the same planting distances. These rootstocks increase the height of the

TABLE 4.-The growth characters of grafted and ungrafted coffee trees planted in field trial 27 at Castañer, P.R. ${ }^{1}$

\begin{tabular}{l|c|c|c|c}
\hline \multirow{2}{*}{ Rootstock } & Scion & Stems or shoots & Girth of main stem & Height of tree \\
Columnaris & Bourbon & $2.93 \pm 0.19$ & $8.15 \pm 0.25$ & $98.72 \pm 2.73$ \\
Excelsa & Do. & $3.60 \pm 0.21$ & $8.87 \pm 0.27$ & $96.71 \pm 2.68$ \\
Robusta & Do. & $2.88 \pm 0.20$ & $7.95 \pm 0.22$ & $98.90 \pm 2.20$ \\
Ungrafted & Do. & $4.16 \pm 0.28$ & $8.69 \pm 0.26$ & $92.77 \pm 2.57$ \\
\hline
\end{tabular}

${ }_{1}^{1}$ The data were collected in May 1965.

grafted trees only slightly. This increase does not seem to create any additional difficulty in harvesting the crop.

\section{CLEAN-COFFEE YIELDS FROM GRAFTED AND \\ UNGRAFTED COFFEE TREES}

In field 27 Bourbon trees ungrafted and those grafted on Columnaris, Excelsa, and Robusta rootstocks differed greatly as to clean-coffee yields. Although the clean-coffee yields of the three types of grafted trees were from 6.82 to 31.98 percent higher than those from the ungrafted Bourbon trees, the differences were not significant at the 5-percent level (table 5).

In several experimental and commercial coffee plantings Puerto Rican and Bourbon trees grafted on Excelsa rootstocks were observed to be generally more productive than ungrafted trees of these scion varieties growing around them.

\section{CHERRY AND CLEAN-BEAN CHARACTERS OF GRAFTED AND UNGRAFTED COFFEE TREES}

Puerto Rican trees grafted on Columnaris, Excelsa, and Robusta rootstocks gave cherry to clean-bean ratios higher than that of the ungrafted 
trees of this variety. Likewise Bourbon trees grafted on Columnaris, Excelsa, and Robusta rootstocks also gave cherry to clean-bean ratios higher than that of the ungrafted trees of this variety (table 6).

Puerto Rican trees grafted on Columnaris, Excelsa, and Robusta rootstocks produced higher proportions of beans of top export-grade (beans

TABLE 5.-The clean-coffee yields from grafted and ungrafted coffee trees growing in field trial 27 at Castañer, P.R. ${ }^{1}$

\begin{tabular}{l|c|c|c}
\hline \multicolumn{1}{c|}{ Rootstock } & Scion & $\begin{array}{c}\text { Mean yield of coffee beans } \\
\text { per acre per year with } \\
\text { 12-percent moisture }\end{array}$ & $\begin{array}{c}\text { Increase of yield as } \\
\text { compared with that from } \\
\text { ungrafted Bourbon trees }\end{array}$ \\
\hline & Bourbon & Pounds & Percent \\
Columnaris & Do. & 559.84 & 6.82 \\
Excelsa & Do. & 691.71 & 31.98 \\
Robusta & Do. & 594.17 & 13.37 \\
Ungrafted & 524.09 & - \\
\hline
\end{tabular}

1 The yield data were collected for the first 4 crops, 1961-64.

2 The differences among the mean yields of all the 4 types of trees are not significant at the 5-percent level.

TABLE 6.-The weight of coffee cherries in 2 field trials required to produce a pound of clean beans with a 12-percent-moisture content ${ }^{1}$

\begin{tabular}{c|l|c|c}
\hline & \multicolumn{1}{|c|}{ Scion } & \multicolumn{2}{|c}{ Coffee cherries (pounds) } \\
\cline { 3 - 4 } Rootstock & & Field trial 25 & Field trial 27 \\
\cline { 2 - 3 } & & 5.39 & - \\
Columnaris & Puerto Rican & 6.01 & 6.09 \\
Do. & Bourbon & 5.52 & - \\
Excelsa & Puerto Rican & 5.76 & 6.15 \\
Do. & Bourbon & 5.41 & - \\
Robusta & Puerto Rican & 5.93 & 5.94 \\
Do. & Bourbon & 5.24 & - \\
Ungrafted & Puerto Rican & 5.68 & 5.87 \\
Do. & Bourbon & & \\
\hline
\end{tabular}

1 These determinations are based on study of coffee cherry samples collected during the 1964 crop.

retained over sieves No. 18 and No. 17) than that of the ungrafted trees of this variety.

Bourbon trees grafted on Columnaris, Excelsa, and Robusta rootstocks produced proportions of beans of top export-grade higher in field trial 27 and lower in field trial 25 than those of the ungrafted trees of the variety (table 7).

Puerto Rican trees grafted on Columnaris, Excelsa, and Robusta root- 
stocks had a lower number of beans per liter than the ungrafted trees of this variety.

Bourbon trees grafted on Columnaris, Excelsa, and Robusta rootstock had a lower number of beans per liter in field trial 27 and higher in field trial 25 than those of the ungrafted trees of this variety.

Puerto Rican trees grafted on Columnaris, Excelsa, and Robusta rootstocks had higher proportions of peaberry beans and lower proportions of triangular beans than those of the ungrafted trees of this variety. The differences between the grafted and the ungrafted trees of this variety as to the proportions of giant beans and flat beans were inconsistent and small.

TABLE 7.-The grading (percentage) of clean beans in 2 field trials from grafted and ungrafted coffee trees secured by passing them through sieves No. 15, No. 17, and No. $18^{1}$

\begin{tabular}{|c|c|c|c|c|c|c|c|c|c|}
\hline \multirow[b]{2}{*}{ Rootstock } & \multirow[b]{2}{*}{ Scion } & \multicolumn{4}{|c|}{ Field trial 25} & \multicolumn{4}{|c|}{ Field trial 27} \\
\hline & & $\begin{array}{c}\text { Beans } \\
\text { under } \\
\text { sieve } \\
\text { No. } 15\end{array}$ & $\begin{array}{c}\text { Beans } \\
\text { over } \\
\text { sieve } \\
\text { No. } 15\end{array}$ & $\begin{array}{c}\text { Beans } \\
\text { over } \\
\text { sieve } \\
\text { No. } 17\end{array}$ & $\begin{array}{c}\text { Beans } \\
\text { over } \\
\text { sieve } \\
\text { No. } 18\end{array}$ & $\begin{array}{c}\text { Beans } \\
\text { under } \\
\text { sieve } \\
\text { No. } 15\end{array}$ & $\begin{array}{c}\text { Beans } \\
\text { over } \\
\text { sieve } \\
\text { No. } 15\end{array}$ & $\begin{array}{c}\text { Beans } \\
\text { over } \\
\text { sieve } \\
\text { No. } 17\end{array}$ & $\begin{array}{c}\text { Beans } \\
\text { over } \\
\text { sieve } \\
\text { No. } 18\end{array}$ \\
\hline Columnaris & Puerto Rican & 6.25 & 31.25 & 54.69 & 7.81 & 一 & - & - & - \\
\hline Do. & Bourbon & 15.63 & 46.88 & 32.81 & 4.69 & 18.75 & 50.00 & 28.13 & 3.13 \\
\hline Excelsa & Puerto Rican & 6.25 & 39.06 & 50.00 & 4.69 & - & - & - & - \\
\hline Do. & Bourbon & 14.06 & 50.00 & 29.69 & 6.25 & 18.75 & 43.75 & 32.81 & 4.69 \\
\hline Robusta & Puerto Rican & 7.81 & 32.81 & 53.13 & 6.25 & - & - & - & - \\
\hline Do. & Bourbon & 10.94 & 51.56 & 31.25 & 6.25 & 15.63 & 53.13 & 26.56 & 4.69 \\
\hline Ungrafted & Puerto Rican & 4.69 & 42.19 & 50.00 & 3.13 & - & 一 & - & - \\
\hline Do. & Bourbon & 9.38 & 46.88 & 39.06 & 4.69 & 18.75 & 54.69 & 21.88 & 4.69 \\
\hline
\end{tabular}

${ }^{1}$ Percentage of beans of different grades is by weight. The beans had 10 - to 11 percent moisture contents.

Bourbon trees grafted on Columnaris, Excelsa, and Robusta rootstocks had lower proportions of flat beans and higher proportions of triangular beans than those of the ungrafted trees of this variety. The differences between the grafted and the ungrafted trees of this variety as to the proportions of giant beans and peaberry beans were rather inconsistent and small (table 8).

The differences between the ungrafted Puerto Rican trees and those grafted on Columnaris, Excelsa, and Robusta rootstocks, as to weight, volume, and specific gravity of beans, were also rather inconsistent and small.

In field trial 25 beans of ungrafted Bourbon had a higher weight and volume and a lower specific gravity than those of beans from trees of this variety grafted on Columnaris, Excelsa, and Robusta rootstocks. 
In field trial 27 beans from ungrafted Bourbon trees had a lower weight and volume and a higher specific gravity than those of beans from trees of this variety grafted on Columnaris, Excelsa, and Robusta rootstocks (table $9)$.

On the basis of the data presented above and the general observations during several crops it can be concluded that the grafted and the ungrafted

TABLE 8.-The size and the shape of clean beans from grafted and ungrafted coffee trees in 2 field trials ${ }^{1}$

\begin{tabular}{|c|c|c|c|c|c|c|c|c|c|c|c|}
\hline \multirow[b]{2}{*}{ Rootstock } & \multirow[b]{2}{*}{ Scion } & \multicolumn{5}{|c|}{ Field trial 25} & \multicolumn{5}{|c|}{ Field trial 27} \\
\hline & & $\begin{array}{c}\text { Beans } \\
\text { per } \\
\text { liter }\end{array}$ & $\begin{array}{l}\text { Giant } \\
\text { beans }\end{array}$ & $\begin{array}{c}\text { Pea- } \\
\text { berry } \\
\text { beans }\end{array}$ & $\underset{\text { Flat }}{\text { beans }}$ & $\begin{array}{c}\text { Trian- } \\
\text { gular } \\
\text { beans }\end{array}$ & $\begin{array}{c}\text { Beans } \\
\text { per } \\
\text { liter }\end{array}$ & $\begin{array}{l}\text { Giant } \\
\text { beans }\end{array}$ & $\begin{array}{l}\text { Pea- } \\
\text { berry } \\
\text { beans }\end{array}$ & $\underset{\text { blat }}{\text { Feans }}$ & $\begin{array}{l}\text { Trian- } \\
\text { gular } \\
\text { beans }\end{array}$ \\
\hline & & $\begin{array}{c}\text { Num- } \\
\text { ber }\end{array}$ & $\begin{array}{l}\text { Per- } \\
\text { cent }\end{array}$ & $\begin{array}{l}\text { Per- } \\
\text { cent }\end{array}$ & $\begin{array}{l}\text { Per- } \\
\text { cent }\end{array}$ & $\begin{array}{l}\text { Per- } \\
\text { cent }\end{array}$ & $\begin{array}{c}\text { Num- } \\
\text { ber }\end{array}$ & $\begin{array}{l}\text { Per- } \\
\text { cent }\end{array}$ & $\begin{array}{l}\text { Per- } \\
\text { cent }\end{array}$ & $\begin{array}{l}\text { Per- } \\
\text { cent }\end{array}$ & $\begin{array}{l}\text { Per- } \\
\text { cent }\end{array}$ \\
\hline Columnaris & Puerto Rican & 4,420 & 0 & 3.17 & 95.11 & 1.72 & - & - & - & - & - \\
\hline Do. & Bourbon & 4,924 & 0 & 8.12 & 84.97 & 6.90 & 5,092 & 0 & 10.37 & 82.48 & 7.15 \\
\hline Excelsa & Puerto Rican & 4,516 & .18 & 5.23 & 93.98 & .62 & - & 一 & - & - & - \\
\hline Do. & Bourbon & 4,780 & 0 & 5.86 & 85.44 & 8.70 & 5,036 & 0 & 8.42 & 84.99 & 6.59 \\
\hline Robusta & Puerto Rican & 4,504 & .18 & 5.68 & 92.36 & 1.78 & - & - & - & - & - \\
\hline Do. & Bourbon & 5,012 & .24 & 4.55 & 89.39 & 5.83 & 5,084 & 0 & 4.17 & 88.28 & 7.55 \\
\hline Ungrafted & Puerto Rican & 4,568 & 0 & 2.36 & 95.10 & 2.54 & - & 一 & - & - & - \\
\hline Do. & Bourbon & 4,724 & .08 & 4.83 & 89.59 & 5.50 & 5,508 & 0 & 4.87 & 89.18 & 5.95 \\
\hline
\end{tabular}

${ }^{1}$ The percentages of beans of different shapes is by number. The beans had 10 to 11-percent moisture contents.

TABLE 9.-The weight, volume, and specific gravity of clean beans produced from grafted and ungrafted coffee trees in 2 field trials ${ }^{1}$

\begin{tabular}{|c|c|c|c|c|c|c|c|}
\hline \multirow[b]{2}{*}{ Rootstock } & \multirow[b]{2}{*}{ Scion } & \multicolumn{3}{|c|}{ Field trial 25} & \multicolumn{3}{|c|}{ Field trial 27} \\
\hline & & $\begin{array}{l}\text { Weight } \\
\text { of } 100 \\
\text { beans }\end{array}$ & $\begin{array}{c}\text { Water } \\
\text { displaced } \\
\text { by } 100 \\
\text { beans }\end{array}$ & $\begin{array}{l}\text { Specific } \\
\text { gravity } \\
\text { of beans }\end{array}$ & $\begin{array}{l}\text { Weight } \\
\text { of } 100 \\
\text { beans }\end{array}$ & \begin{tabular}{|c|} 
Water \\
displaced \\
by 100 \\
beans
\end{tabular} & $\begin{array}{l}\text { Specific } \\
\text { gravity } \\
\text { of beans }\end{array}$ \\
\hline & & Grams & $\begin{array}{l}\text { Cubic } \\
\text { centi- } \\
\text { meters }\end{array}$ & - & Grams & $\begin{array}{l}\text { Cubic } \\
\text { centi- } \\
\text { meters }\end{array}$ & \\
\hline Columnaris & Puerto Rican & 15.40 & 14.0 & 1.100 & - & - & - \\
\hline Do. & Bourbon & 14.20 & 12.5 & 1.136 & 13.75 & 12.5 & 1.100 \\
\hline Excelsa & Puerto Rican & 14.80 & 13.0 & 1.138 & - & - & - \\
\hline Do. & Bourbon & 13.65 & 12.0 & 1.137 & 12.77 & 11.5 & 1.110 \\
\hline Robusta & Puerto Rican & 15.20 & 13.5 & 1.125 & - & - & - \\
\hline Do. & Bourbon & 13.35 & 12.0 & 1.112 & 13.42 & 12.0 & 1.118 \\
\hline Ungrafted & Puerto Rican & 15.35 & 13.5 & 1.137 & - & - & - \\
\hline Do. & Bourbon & 14.45 & 13.0 & 1.111 & 12.35 & 11.0 & 1.122 \\
\hline
\end{tabular}

1 The beans had 10- to 11-percent moisture contents. 
trees of Puerto Rican and Bourbon varieties did not differ much in the characters of their beans.

The cup qualities of beans from grafted and ungrafted coffee trees were not compared. However, the differences in this respect, if any, are expected to be very small, as the characters of seeds of scion varieties are not expected to be greatly affected by the rootstocks.

\section{SUITABILITY OF EXCELSA FOR USE AS ROOTSTOCK FOR PUERTO RICAN AND BOURBON COFFEES}

General observations and data in tables 1 to 9 lead to the conclusion that Excelsa is the best rootstock for Puerto Rican and Bourbon scions.

Only a small percentage of the trees with Excelsa rootstocks and Puerto Rican and Bourbon scions showed symptoms of rootstock and scion incompatibility, and died possibly from root-rot disease.

Excelsa rootstock did not significantly alter tree growth nor the cherry and clean-bean characters of the scion varieties. In other words, such effects did not seem to be great from the point of view of commercial production.

Puerto Rican and Bourbon trees with Excelsa rootstocks were observed to be generally much productive.

Columnaris is also a good rootstock, but Bourbon grafted on it gave a relatively lower yield (table 5).

\section{SUMMARY}

The performance of grafted and ungrafted coffee trees was compared in three large field trials for up to 6 years.

The data and general observations as to rootstock and scion incompatibility, incidence of the root rot disease, growth characters of trees, coffee yield, and bean characters, indicated that, of the six rootstocks tested, Excelsa seems to be the best for Puerto Rican and Bourbon varieties.

In a replicated field trial during which four crops were harvested, Bourbon trees grafted on Excelsa produced annually 31.98 percent more market coffee than ungrafted trees of the Bourbon variety. This difference did not attain the 5-percent level of significance.

\section{RESUMEN}

Durante 6 años consecutivos se llevaron a cabo tres experimentos grandes de campo para comparar el comportamiento de arbustos de café injertados $\mathrm{y}$ sin injertar.

Los datos obtenidos y las observaciones hechas, en cuanto a la incompatibilidad del patrón y el injerto, la incidencia de la enfermedad que pudre la raíz, las características del crecimiento de los arbustos, el rendimiento y los caracteres del grano, indicaron que de los seis patrones probados y 
comparados, el patrón de Excelsa parece ser el mejor para injertar las variedades Puerto Rico y Bourbón.

En un experimento repetido en el cual se hicieron cuatro cosechas, los arbustos que se originaron de injertos de la variedad Bourbón en patrones de Excelsa, produjeron anualmente 31.98 por ciento más de café mercadeable que los arbustos de la variedad Bourbón sin injertar. Esta diferencia no logró llegar al nivel del 5 por ciento de significación.

\section{LITERATURE CITED}

1. Abruña, F., Vicente-Chandler, J., Silva, S., and Gracia, W., Productivity of nine coffee varieties growing under intensive management in full sunlight and partial shade in the Coffee Region of Puerto Rico, J. Agr. Univ. P.R. 49 (2): $244-53,1965$.

2. De Gialluly, Max, Factors affecting the inherent quality of green coffee, Advances in Coffee Production Technology, Coffee and Tea Industries, New York, N.Y., pp. 88-92, 1959.

3. Singh Dhaliwal, T., Desarrollo de estirpes o biotipos superiores de café mediante la selección, la hibridación y la propagación asexual, para su cultivo en Puerto Rico, Rev. de Agr. de P.R., 44 (2): 59-77, 1957.

4. - Recent Experiments on Coffee Grafting in Puerto Rico, Agr. Exp. Sta. Univ. P.R., Tech. Paper 30, 1961.

5. - - Progress Report of the Project Coffee Breeding in Puerto Rico, 1954-65, Agr. Exp. Sta. Univ. P.R., Miscel. Pub. 53, 1965.

6. Singh Dhaliwal, T., and Torres Sepúlveda, A., Recent Experiments on Rooting Coffee-Stem Cuttings in Puerto Rico, Agr. Exp. Sta. Univ. P.R., Tech. Paper 33, 1961.

7. 一, López Rosa, J. H., Steiner, G., Igaravídez, L., and Torres Sepúlveda, A., Studies on Coffee Root Rot and Horticultural Practices for Its Amelioration, Agr. Exp. Sta. Univ. P. R. Tech. Paper 36, 1963.

8. Wellman, Frederick L., Recomendaciones para Mejorar el Cultivo del Café en Puerto Rico, Est. Exp. Agr. Univ. P. R. Bol. 153, 1960. 